Jan Sosnowski

Uniwersytet Łódzki

Instytut Rusycystyki

Zakład Językoznawstwa

\title{
O IMIONACH DWUCZLONOWYCH W HISTORII JĘZYKA POLSKIEGO I ROSYJSKIEGO
}

W dawnych językach słowiańskich wyróżniamy trzy podstawowe grupy imion osobowych z punktu widzenia ich pochodzenia: imiona jednotematowe odapelatywne, imiona dwuczłonowe oraz imiona chrześcijańskie. Imiona te występują m.in. zarówno w dawnej polszczyźnie, jak i ruszczyźnie. Imiona odapelatywne jednotematowe oraz imiona dwuczłonowe są imionami rodzimymi na gruncie słowiańskim, zaś imiona chrześcijańskie to imiona obce z pochodzenia, zapożyczone.

Celem artykułu jest porównanie aktywności męskich imion dwuczłonowych (złożonych) w historii języka polskiego i historii języka rosyjskiego.

Obecność imion dwuczłonowych we wszystkich językach słowiańskich wskazuje na prasłowiańską genezę tej formacji. Sięga ona swymi korzeniami struktur indoeuropejskich.

Budowę imion dwuczłonowych przedstawiam w skrócie poniżej.

Człon pierwszy, początkowy może zawierać formy pierwiastkowe (czyli rdzenie), tematy werbalne, tematy nominalne, formy przypadkowe rzeczowników i zaimków, formy komparatywne przymiotników, wyrazy nieodmienne (indeclinabilia).

Wśród staropolskich imion dwuczłonowych wyróżniamy siedem form pierwiastkowych: bro (por. bronić < ps. *borniti 'osłaniać orężem, strzec', 'nie pozwalać' SP), by (por. być < ps. *byti 'istnieć, żyć; być obecnym; zdarzyć się; mieć miejsce' - SP), czę (por. ps. *cęti 'zacząć, rozpocząć' obecne w prefiksalnych czasownikach *načęti, *počęti, *začęti SP), da (por. dać < ps. *dati 'dać, przekazać na własność; obdarzyć czym', 'dostarczyć' - SP ), dzie (por. ps. *děti 
'położyć, postawić', 'zrobić, uczynić', także 'rzec, powiedzieć' - SP), ję (por.jąc < ps. *jęti 'wziąć, chwycić', też dawne znacz. 'zacząć', por. prefiksalne czasowniki objać, pojać, wziać itd. - wg Sław.), zna (por. ps. *znati 'znać, wiedzieć' - Bor.). Są one poprzedzone prepozycjami czyli przyimkami (wyjątkowe są formy bez przyimków), por. np. Zbrostaw, Przybywoj, Naczęrad, Niedamir, Zdziewit, Objęstaw, Poznamir, oraz formy bez przyimków, por. np. Brosław, Bygost, Dziebor. Wśród imion staroruskich mamy pierwiastki: by (por. strus. byti), da (por. dati), dě (zob. wyżej *děti), ja- (<*ję, zob. wyżej *jęti), por. Izbygněvъ, Nedabylı, Sdeslavъ, Izjaslavъ, por. też formy bez przyimków: Javolodı, może też Byslavъ.

Imiona z tematem werbalnym w członie początkowym stanowią na gruncie słowiańskim formację produktywną, a w staropolszczyźnie i ruszczyźnie bardzo liczną (najliczniejsza). Wyróżnia się tu trzy następujące typy (tu i niżej podaję przykłady polskie i rosyjskie): a) z tematem aorystu (i jednocześnie infinitiwu) na -ě-: pol. Chociestaw, Chociebor (por. chcieć i stpol. archaizm chocieć $<$ ps. *chotèti 'mieć chęć, chcieć, pragnacé' - Bor.), Wielemyst (por. scs. velěti 'kazać, rozkazywać' - Stsł., stpol. wielić 'rozkazywać, nakazywać' - SStp.), ros. Chotěslavb (por. strus. chotěti 'chcieć, pragnąć' - Srezn.), Velegostb (por. strus. velět $i$ 'kazać, nakazywać'); b) z tematem aorystu (infinitiwu) na -i-: pol. Bronisław (por. wyżej bronić), Sędziwoj (por. sądzić, stpol. też sędzić < ps. *soditi 'oceniać, osądzać; sprawować sąd' - Bor.), ros. Borislavz (por. strus. boriti 'podbijać, zdobywać' - SRJ), Ratiborb (por. strus. ratitisja 'walczyć, wojować' - SRJ); c) z formą imperatywu na -i: pol. Dzirżykraj / Dzierżykraj (por. dzierżyć, dzierżę, stpol. dzierżać / dzierżeć, dzierży oraz dzirżeć, dzirży 'trzymać; posiadać, władać czymś' - Bor.), Włodzisław (por. stpol. włodać< ps. *voldati od *volsti, *voldo 'panować, władać' - Bor.), Stanisław (por. stać, stanę < ps. *stati, * stano 'stanąć; podnieść się' - Bor.), Będzimir (por. być, będę), ros. Volodimerb (por. strus. voloděti 'władać' - SRJ), Stanimirz (por. strus. stati, stanu 'stanąć, nastać' - Srezn.), Židislavъ (por. strus. židati 'oczekiwać' - SRJ), Budimerъ (por. byti, budu - SRJ), oraz z formą imperatywu na dawną *-j-: pol. Dadzbog, ros. Dažbogz (por. imperatyw od dati: *dadjb).

Tematy nominalne na -ŏ- notujemy w następujących imionach, por. np.: pol. Bogomit, Mitogost, Lutogniew (por. luty < ps. *ljutъ 'budzący grozę, okrutny, dziki; ostry, piekący' Sław.), Samosąd (dawne tematy na -̌o-), Niegostaw (dawny temat na - $\bar{a}$-: niega - wyraz ten jest poświadczony w jęz. strus., por. něga 'radość, zadowolenie'-SRJ), Siemomyst, Siemowit (dawny temat na -āa-: ps. * sěmbja 'ród,

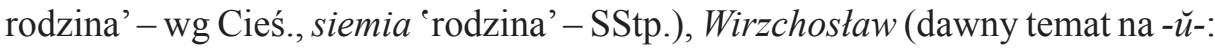
wirzch, por. stpol. wierzch, wirzch, wirch 'górna lub zewnętrzna część czegoś;

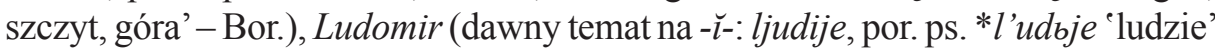


oraz dial. *l'udъ 'zbiorowisko ludzi' - Bor.), ros.: Bogdanъ, Miroslavъ (por. strus. mirz 'świat; ludzkość, ludzie' oraz także mirb 'spokój; zgoda; pokój' - SRJ), Radogostb (por. strus. radz 'rad, zadowolony, radosny' - SRJ), Svjatopolkъ (por. strus. svjatı ‘święty' - SRJ, wcześniej, w czasach pogańskich 'silny' - Brück.), Jaroslavb (por. strus. jaryj 'gniewny; okrutny; śmiały' - Srezn., pierwotne znacz.

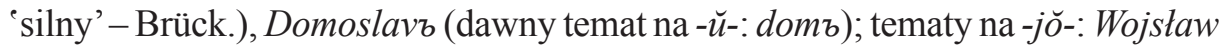
(por. wój 'żołnierz’ - Brück.), Bożebor (od przym. boży), ros. Voislavı/Voeslavz, Voigostb (por. strus. vojb w $1 \mathrm{~m}$. 'wojowie, siły zbrojne' - SRJ), Vseslavb (por. zaimek vbsb 'cały, wszystek' - SRJ), Gosteljubb (dawny temat na - -̌-: gostb 'gość; kupiec, także cudzoziemski kupiec' - SRJ), Uegostb / Ujgostb (por. ui, czyli ujb 'wuj' - Srezn.); przykład z tematem zaimkowym: Samostradz.

Formy przypadkowe rzeczowników i zaimków znajdujemy na przykład w następujących imionach: pol. Boguchwat, Bratumil, Dobiegniew (por. stpol. dobie 'w stosownym czasie' - L sg od dawn. doba 'stosowność; stosowna pora; czas, pora' - Bańk.); Domarad, Siedlewit (por. sioło i *siodto < ps. * sedlo 'wieś' Bor.), Sobiesad; ros. Boguslavъ, Boguchvalı, Domažirz.

Formy komparatywne przymiotników odnotowujemy w takich oto imionach, por. przykłady pol.: Bolesław (por. ps. *bol'bjb 'większy, lepszy', *bol'e 'lepiej, więcej, bardziej' - SP), Dalebor (por. ps. *dal'e 'dalej' - SP), Uniegost (por. scs. unii, czyli unüjb 'lepszy', uněi, czyli unějb ‘lepiej’ - Stsł.), Więcemit (por. więcej, więce - SStp.), Wyszemir (por. stpol. wyszy, wyszszy 'wyższy' - Bor.) oraz ros. Boleslavъ, Uněměrz / Uněmirz, Vjačeslavъ (por. strus. vjaščij, vjatčij 'większy, silniejszy' oraz przysł. vjače - SRJ), Vyšeslavb.

Wyrazy nieodmienne (indeclinabilia) w pierwszym członie, czyli członie początkowym, to przysłówki, przyimki (prepozycje) i negacja nie-.

Imiona z przysłówkami występują w materiale staropolskim: por. np. Blizbor, Dobrzegniew, Spycigniew (por. *spyci 'darmo' - Brück., 'darmo = daremnie'; scs. spyti 'daremnie, bezpodstawnie'- Stsł.), Takomyst. W materiale staroruskim nie stwierdziłem obecności ewidentnych form imiennych z przysłówkami.

Przykłady imion z przyimkami i z negacją - por. pol. imiona Izbor, Nadar, Nadmir, Niegrod, Osięgniew, Przemyst, Przedbor, Przywit, Smyst, Zamir, por. też przykłady, w których człon początkowy jest złożony z prepozycji i pierwiastka werbalnego: Przybystaw, Zbygniew, Naczęmir, Niedamir, Objęsław; por. ros. imiona Bezděd , Vněgъ / Voněgъ, Izborъ, Naslavъ, Negostb, Obněgъ, Peregostb, Promyslı, także Izbygněvъ, Perejaslavъ, Rozdamirb.

Człon drugi (końcowy) ma w słowiańskich imionach złożonych formę ujednoliconą - niezależnie od leksemu motywującego przybrał w prasłowiańskich

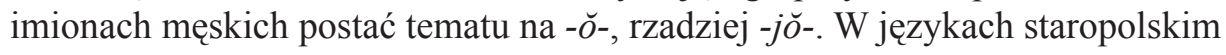


i staroruskim imiona te zakończone są na spółgłoskę twardą lub $j$; ponadto, bardzo możliwe, że staroruskie imiona z drugim członem gost zakończone były na spółgłoskę miękką. Chyba jedyny przykład imienia męskiego na - $a$ w staroruszczyźnie (nie licząc neologizmów takich jak Padinoga) to Nesda $(\mathrm{Ne}+s+d a$, od dati) z XII wieku (w gramocie brzozowej oraz w latopisie nowogrodzkim; por. też formę Neszdičb w gramocie brzozowej z XI/XII wieku). Wśród przykładów Andrieja Zalizniaka wydobytych z gramot brzozowych napotkałem formę dopełniacza imienia Domagostb - ot Domagosti - według deklinacji na -̌̌-. Człon końcowy częściej jest pochodzenia imiennego (zwykle rzeczownikowego), rzadziej werbalnego (czyli czasownikowego). Przykłady imion z członem imiennym por. pol. Kazimir, Bronisław, Wroc(s)ław, Dadzbog, Sulibrat, Radogost, Świętopetk (por. *petk, pótk< ps. *plkъ 'gromada ludzi; lud; oddział wojska' - Bor., Brück.), Mściwoj, Mitostryj, Radowuj; por. ros.: Mstbbogъ, Toligněvъ, Vitogostb, Volodimerъ (por. ps. *měr 'wielki') i Volodimirs (mirъ zob. wyżej), Sudimirъ, Deržikraj, Radoněgъ, Svjatopolkъ, Vorotislavb. Przykłady imion z końcowym członem werbalnym: pol. Częstobor, Zdziebąd / Zdziebud, Gościwid, Ninowłod, ros. Ratiborb, Snowidz, Jawolodъ, a także Nesda i Bogdanъ (danъ - od dati), [wg Malec, 1971; Skulina, 1974; Sosnowski, 2012; Zalizniak, 2004].

Prof. Maria Malec zgrupowała około 600 staropolskich imion dwuczłonowych, w tym ponad 100 zrekonstruowanych na podstawie nazw miejscowych. Korzystała głównie ze Stownika staropolskich nazw osobowych - materiały średniowieczne do roku 1500 [Malec, 1971, s. 133]. Nie jest to lista pełna, istnieją bowiem kolejne propozycje rekonstrukcji imion zachowanych w nazwach miejscowych [Bańkowski, 1984], próby te wymagają jednak dalszej wnikliwej analizy. Kilkadziesiąt dotąd nieznanych imion zrekonstruowano na podstawie nazwisk zawartych w Stowniku nazwisk współcześnie w Polsce używanych [Kraków 1992-1994; zob. Malec, 1998, s. 100; Skowronek, 1995, s. 73-100].

Około 130 staroruskich imion dwuczłonowych wydobył z dawnych źródeł do XIV wieku włącznie, głównie latopisów, Tadeusz Skulina [1974, s. 151-237]. Skompletowany przeze mnie spis staroruskich imion dwuczłonowych liczy obecnie około 400 jednostek leksykalnych. Ponad połowę materiału stanowią imiona zrekonstruowane na podstawie nazw miejscowych. Większość toponimów z zachowanymi $w$ ich podstawach imionami pochodzi z materiałów nowogrodzkich, zbadanych przez Walerija Wasiliewa i przeze mnie [Sosnowski, 2002; Wasiliew, 2005]. Tak więc liczba imion dwuczłonowych będących w użyciu na Rusi we wczesnym średniowieczu (przed przyjęciem chrześcijaństwa, ale może też i niedługo po chrystianizacji Rusi) musiała być dużo większa niż wskazują na to dane latopisów. Imiona te były prawdopodobnie używane nie tylko wśród 
najwyższych warstw społeczeństwa (jak to się zwykle przyjmuje), choć niektóre były niewątpliwie zarezerwowane dla dynastii i bojarów.

Arystokracja indoeuropejska - jak pisał Tadeusz Milewski - używała imion dwuczłonowych, ci zaś, którzy do niej nie należeli, nosili imiona jednoczłonowe odapelatywne [1969, s. 9]. M. Malec stwierdziła, że w czasach historycznych podział ten nie był już w sposób rygorystyczny przestrzegany. W Bulli gnieźnieńskiej (1136) imiona chłopskie to w znacznej części nazwy dwuczłonowe; obok nich mamy imiona odapelatywne, z przewaga tych ostatnich [Malec, 1998, s. 105]1'.

Znamienny jednak jest fakt, że w imiennictwie Piastów rozpowszechnione są imiona dwuczłonowe, są też tutaj imiona jednotematowe, będące prawdopodobnie skróceniami imion złożonych, por. Bolesław, Kazimierz, Przemyst, Władysław, a także Mieszko (od Miecsław), Leszek (najpierw Lestek), Leszko (od Lestsław), Bolek, Bolko (od Bolesław), Kazek, Kazko (od Kazimir), Przemek, Przemko (od Przemystaw). Historycy uważają, że wymienione imiona były zastrzeżone dla dynastii piastowskiej [Malec, 2001, s. 86].

Pierwszy koronowany władca Polski nosił imię Bolesław. Był to syn Mieszka I, Bolesław I Chrobry, twórca potęgi wczesnofeudalnego państwa polskiego. Bolesław II, okryty złą sławą jako zabójca biskupa Stanisława, nosił przydomki Szczodry i Śmiały. Bolesław III Krzywousty to ostatni z wielkich Bolesławów; on jednak nie uwieńczył swych skroni królewską koroną. Książęce imię Bolesław było szczególnie popularne wśród Piastów śląskich - niektórzy z nich znani byli pod imieniem skróconym Bolko (lub Bolek). Imię Kazimierz po raz pierwszy pojawia się wśród Piastów w 1016 roku, w roku narodzin Kazimierza I Odnowiciela; książę otrzymał drugie imię Karol, świadczące o wielkich ambicjach rodziny. Najsłynniejszy z piastowskich Kazimierzów to król Kazimierz III Wielki, syn Władysława Łokietka, ostatni z Piastów na tronie polskim. Przekształcił Polskę, która awansowała na silny organizm polityczny i gospodarczy; zmarł w 1370 roku. Przemysł II, najpotężniejszy z książąt piastowskich w końcu XIII wieku, koronował się na króla Polski w 1296 roku, wkrótce jednak został zamordowany. Spośród Władysławów wymieńmy najznakomitszego, czyli Władysława I Łokietka; król ten doprowadził do zjednoczenia większości ziem polskich po okresie rozdrobnienia dzielnicowego. Nie można tu pominąć imienia pierwszego księcia dynastii, Siemowita, syna legendarnego Piasta. Autentyczność Siemowita nie jest już dziś podważana. Później imię to będzie spotykane wśród książąt mazowieckich (jeszcze w XV wieku).

Zaledwie 2\% wieśniaków wymienionych w bulli nosiło imiona chrześcijańskie [Leciejewicz, 1989, s. 291]. 
Twórcą państwa polskiego był Mieszko I, który w 966 roku przyjął chrzest i jako pierwszy władca włączał się do polityki europejskiej. Mieszko był synem Siemomysła, a ten ostatni - synem Leszka (czy raczej Lestka) i wnukiem Siemowita [tu i wyżej wg Garlicki, 1991, s. 9-253]. Pod imionami skróconymi znani byli jeszcze między innymi książęta: Bolko (książę opolski), Kaźko słupski, Leszek Biały (książę sandomierski i krakowski) oraz Przemko (książę głogowski i poznański).

Co się tyczy Jagiellonów, to zwróćmy uwagę na fakt, że ochrzczeni w katedrze wawelskiej książęta litewscy otrzymali imiona dwuczłonowe: Jagiełłę nazwano Władystawem, Korygiełłę Kazimierzem, zaś Świdrygiełłę Bolesławem. Tak więc zachowana została tradycja imiennicza panującego domu polskiego [Malec, 2001, s. 86]. Wśród Jagiellonów spotykane są dwa imiona dwuczłonowe: wspomniany Władysław (oprócz Jagiełły - Władysław III Warneńczyk i Władysław II Jagiellończyk, król czeski i węgierski) oraz Kazimierz (Kazimierz IV Jagiellończyk i jego syn Kazimierz, królewicz polski i litewski, kanonizowany w 1521 roku). Dodajmy jeszcze, że wśród Wazów mamy Władysława IV i Jana II Kazimierza.

Do staroruskich imion dynastycznych należą (chodzi o średniowieczną dynastię Rurykowiczów): Boriş (skrócenie od Borislavb), Brjačislavb, Volodimerb / Volodimirz, Vsevolodъ, Vseslavъ, Vjačeslavъ, Izjaslavъ, Mstislavъ, Rogovolodъ, Rostislavb, Svjatopolkъ, Svjatoslavъ oraz Jarostavъ. Imię Svjatoslavъ noszą wielcy książęta kijowscy, poczynając od wojowniczego Światosława syna Igora a wnuka Ruryka. Wielki książę Włodzimierz (Volodimer) wprowadził chrześcijaństwo w Rusi Kijowskiej jako religię państwową w 988 roku, czym na zawsze zyskał sobie świętość i przydomek Wielki. Synem Włodzimierza Wielkiego był Jarosław zwany Mądrym, polityk wytrawny i dalekowidzący. Najstarszy syn wielkiego Włodzimierza, Świętopełk, zabójca trzech braci, przeszedł do historii z przydomkiem Przeklęty. Dwaj z trzech zamordowanych w 1015 roku przez Świętopełka braci to Borys i Gleb, uznani w 1072 roku przez cerkiew ruską za pierwszych rodzimych świętych. Boriš, a także Glebъ - ale to imię nie jest przedmiotem mojej analizy ${ }^{2}$ - są imionami książąt, jak np. Borys Wasylkowicz, książę rostowski (XIII w.). Popularnym imieniem wśród książąt ruskich było imię Izjasłavb - spolszczona forma: Izasław. Izasław to np. syn Jarosława Mądrego, który objął po nim rządy w Kijowie, tracił je dwukrotnie i odzyskiwał przy pomocy Polaków. Ostatni z dynastii Rurykowiczów noszący imię dwuczłonowe to wielki książę włodzimierski Jarosław, otruty przez Tatarów w 1271 roku. Później

2 Jest to prawdopodobnie zeslawizowany wariant staroskandynawskiego imienia Gudleifr, choć istnieje również hipoteza słowiańskiego pochodzenia tej nazwy [Hrynkiewicz-Adamskich, 2012, s. 194; Wójtowicz, 1986, s. 39-40]. 
wśród władców dawnej Rusi i Rosji nie napotkamy już imion dwuczłonowych, nie licząc znamienitego bojara, obwołanego carem w 1598 roku, Borysa Godunowa (zmarł w 1605 roku) [wg Bazylow, 1975, s. 27-127]. Tak więc wśród panujących w Polsce niektóre imiona dwuczłonowe, co prawda bardzo nieliczne, zachowują się niepomiernie dłużej niż wśród władców Rusi (i Rosji).

Po wprowadzeniu chrześcijaństwa w Polsce i na Rusi imię złożone, dwuczłonowe mogło być jednym z dwóch - obok chrześcijańskiego (chrzestnego). U książąt piastowskich chrześcijańskim imieniem Mieszka II jest Lambert, Kazimierza I - jak wspomniałem wyżej - Karol. Uczeni przypuszczają, że drugim imieniem Mieszka I mógł być Dagobert. Przykłady osób spoza dynastii, ale z wyższych warstw społecznych średniowiecza: Jan Gniewomir, wojskowy i Świętosław Konstanty [Hertel, 1979, s. 125-142]. M. Malec wymienia jeszcze następujących nosicieli dwóch imion : Stanislao dicto Iwan (1407), Ratyborio alias Urbano i innych [2001, s. 81].

Najbardziej chyba znaną pod dwoma imionami osobistością na Rusi jest namiestnik nowogrodzki w XI wieku Ostromir - Iosif, który zamówił ewangeliarz u diakona Grigorija. Pisze o nim Grigorij w posłowiu do ewangeliarza (zwanego Ewangeliarzem Ostromira) w sposób następujący: „Napisachъ že euangelie se rabu božiju narečenu sušču vъ krъščenii Iosifъ a mirssky Ostromirъ”. Wielki książę Włodzimierz I otrzymał na chrzcie imię Vasilij: por. zapis w latopisie: „Se azъ knjaz’ velikyi Volodimerъ, narečennyi v svjatěmь kreščenii Vasilie, synъ Svjatoslavlı, vnukъ Igorevъ i knjagyni Olgy". Książęta średniowieczni znani byli pod swymi imionami rodzimymi, zaś imię chrześcijańskie (chrzestne) wymieniane było najczęściej przy okazji narodzin lub śmierci księcia, por. np.: 1) „Rodisja [...] u Jaroslava synъ Michailъ, a knjaže imja Izjaslavъ, a vъnukъ Volodimirı” (z latopisu, pod 1190 rokiem); tak więc imię dwuczłonowe określane jest jako imię książęce - knjaže imja. 2) „Prestavisja [czyli zmarł - przyp. J.S.] velikyi knjazь Vsevolodъ imenovanyi v svjatomъ kreščenьi Dmitrii synъ Gjurgevъ [...] vnukъ Volodimera Monomacha" (Latopis Laurentego, pod 1212 rokiem) [trzy ostatnie konteksty: Skulina, 1974, s. 177, 231, 233].

$$
* * *
$$

W średniowieczu - zarówno w okresie przedpiśmiennym, jak i w ciągu kilku wieków po przyjęciu chrześcijaństwa - imiona dwuczłonowe stanowiły bardzo aktywny i rozpowszechniony element nazewnictwa osobowego Słowian. Świadczą o tym chociażby przytoczone wyżej liczby - co najmniej 600 odnotowanych imion w antroponimii staropolskiej i około 400 imion - w staroruskiej (łącznie 
z rekonstrukcjami na bazie toponimów). Do najczęstszych staropolskich imion należą: Bolesław, Bogusław, Dobrogost, Jarosław, Kazimir, Mironieg, Mirosław, Świętosław, Stanisław, Więcesław, Włodzisław / Władzisław / Władysław, Wojciech / Wociech, Zbygniew, a także Włodzimir / Władzimir, Dadzbog, Przemyst, Sambor i Świętopetk. Najczęściej notowane imiona staroruskie to Borisъ (skrócenie od Borislavb), Izjaslavb, Jaroslavb, Mbstislavb / Mstislavb, Rostislavb, Svjatoslavъ, Volodimerb / Volodimirb, Vsevolod b oraz Jaropolkъ, Miroslavъ, Vjačeslavъ, Volodislavı, Zavidъ i Žiroslav. Tak więc imiona bardzo aktywne w obu językach to: Jarostaw / Jaroslavb, Mirostaw/Miroslavb, Świętosław / Svjatoslavb, Więcesław / Vjačeslavъ, Włodzisław (i warianty) / Volodislavъ, Włodzimir / Volodimerb.

W Polsce imiona dwuczłonowe zostały ostatecznie wyparte - z pewnymi wyjątkami - przez imiona chrześcijańskie na przełomie XV i XVI wieku [Karpluk, 1957, s. 179-187, 381-392]. Na Rusi proces ten nastapił nieco wcześniej. Już w XIV wieku malało tam znaczenie imion dwuczłonowych i w ciagu XIV-XV wieku wyszły one z użycia [Wójtowicz, 1986, s. 25]. Na utrwalenie pozycji imion chrześcijańskich w Polsce miały wpływ zalecenia soboru trydenckiego (1545-1563), aby na chrzcie nadawać imiona świętych [Malec, 2002, s. 300].

W Polsce nie zaprzestano nadawania dzieciom imion świętych Kościoła: Czesław, Kazimierz, Stanisław, Wacław (przekształcenie imienia Więcesław / Więc(s)ław), Władysław, Wojciech; weszły one do kanonu imion chrześcijańskich [Malec, 1996, s. 10]. Wśród wymienionych nazw są imiona świętych i błogosławionych z Polski, Czech, Litwy i Weggier - żyli oni od X do XV wieku. Święty Wacław to książę czeski, patron Czech, żył w X wieku. Święty Wojciech, jeden z głównych patronów Kościoła katolickiego i Polski, był biskupem praskim, zginął śmiercią męczeńską jako misjonarz w Prusach. Święty Stanisław ze Szczepanowa był biskupem krakowskim, za nieposłuszeństwo wobec króla Bolesława Śmiałego skazany przez niego na śmierć. Święty Władysław to król Wegier od roku 1077. Błogosławiony Czesław przez pewien czas pełnił funkcje prowincjała zakonu dominikanów w Polsce (żył na przełomie XII i XIII wieku). I wreszcie święty Kazimierz, królewicz, syn Kazimierza IV Jagiellończyka, jest patronem Polski i Litwy.

W rodzinach szlacheckich utrzymywały się przez jakiś czas tradycje nadawania niektórych innych imion dwuczłonowych, a mianowicie: Bronisław, Dadzibog, Dobrogost, Dziersław, Jarosław, Mirosław, Mścisław, Przemysław, Przecław, Włodzimierz, Zbigniew - spotykane są jeszcze w XVI i XVII wieku. W XVIII wieku notujemy dalszy spadek używalności tych imion [Malec, 1996, s. 10]. 
Przenieśmy się znowu na wschodnią Słowiańszczyznę - do państwa moskiewskiego. W materiale XV-wiecznych akt Rusi północno-wschodniej odnotowano następujące imiona dwuczłonowe, ze skróceniem Boris włącznie: Bogdan, Boris, Volodimer, Vjačeslav, Izjaslav i Jaroslav. Boris i Volodimer są imionami ruskich świętych.

Zakres społeczny imienia Volodimer jest szeroki (szerszy niż przed XIV wiekiem), ale wśród niższych warstw społecznych nie jest jeszcze notowane. Ma miejsce upowszechnienie imienia Boris (obok Glěb), związane z kultem Borysa i Gleba, młodszych synów Włodzimierza Wielkiego zabitych w czasie walk o tron kijowski (o czym wspominałem wyżej). Wśród nosicieli imienia Boris w XV wieku są zarówno książęta, jak i chłopi [wg Wójtowicz, 1986].

W Stowniku staroruskich imion osobowych Nikołaja Tupikowa [1989] znajdujemy imię Kazimir, odnoszące się do czterech mieszkańców ziemi nowogrodzkiej (XV-XVI w.). Jest wśród nich Wasilej Kazimir, wysoki urzędnik państwowy namiestnik nowogrodzki, oraz Sidko Kazimir - rolnik (Sidko od Sidor / Isidor). Imię Kazimir jest więc ich drugim imieniem, podczas gdy derywat Kazimirec jest pierwszym imieniem innego osobnika. Odnotowujemy więc tutaj wpływ polski na antroponimię nowogrodzką. Wśród patronimików N. Tupikow przytacza dwie formy: Kazimirovič (Wasilij Kazimirowicz występuje w bylinach) oraz Kazimirov (Stiepan Iwanow syn Kazimirow był starostą ziemskim z Uglicza, 1691 r.).

W zbadanych przeze mnie rejestrach podatkowych państwa moskiewskiego XVI wieku [Kałaczow, 1872-1877] zanotowano około 11000 osób - właścicieli ziemskich. Duża liczba osób nosi imię Bogdan (165), dalej jest Boris (70 osób) i Volodimier (około 60). Bogdan nie było oficjalnym, chrześcijańskim imieniem zatwierdzonym przez Cerkiew. Popularność imienia wynikała najprawdopodobniej z jego religijnej formy. Najwięcej książąt - bodaj sześciu - naliczyłem wśród nosicieli imienia Boris, jest tu też wspomniany wyżej bojar, od roku 1598 car, Borys Fiodorowicz Godunow. Wymienione trzy imiona występują - niezbyt często - również w nazewnictwie ludności prostej w końcu XV i w XVI wieku [Sosnowski, 2012, s. 446-447].

Dla XVII wieku dysponujemy danymi dotyczącymi mieszkańców miast. Wśród 114 częstszych imion tej warstwy społecznej w sześciu dużych miastach Rosji są Bogdan (w formie Bogdaško), Boris (Borisko) oraz Volodimer/Volodimir (Volodja). Dwa pierwsze imiona są dość częste, Bogdaško należy nawet do dość popularnych [wg Zinin, 1972].

Renesans imion dwuczłonowych ma miejsce w XIX wieku. W Polsce wiąże się z ogólnym zainteresowaniem przeszłością kraju po rozbiorach, z chęcią ocalenia i przywrócenia zapomnianych elementów dawnej i rodzimej kultury 
[Malec, 1996, s. 11]. W Rosji odrodzenie się dawnego imiennictwa ruskiego było związane z romantyzmem i ruchem słowianofilskim, z powrotem do rdzennie słowiańskich wartości przeszłości. Ten okres jednak nie jest objęty zakresem moich badań. Dodajmy jeszcze, że nigdy już w historii imiona dwuczłonowe nie będą tak popularne jak w staropolszczyźnie i w dawnej ruszczyźnie.

\section{ROZWIĄZANIA SKRÓTÓW}

\section{Skróty słowników}

Bańk. - BAŃKowsKi Andrzej, 2000, Etymologiczny słownik języka polskiego, t. 1-2, Warszawa.

Bor. - Boryś Wiesław, 2005, Słownik etymologiczny języka polskiego, Kraków.

Brück. - BRÜCKNER Aleksander, 1974, Słownik etymologiczny języka polskiego, Warszawa.

Cieś. - CIEŚliKowa Aleksandra, 2000, Słownik etymologiczno-motywacyjny staropolskich nazw osobowych, cz. 1: Odapelatywne nazwy osobowe, oprac. eadem et al., Kraków.

Sław. - SŁAWSKI Franciszek, 1952-1982, Słownik etymologiczny języka polskiego, t. 1-4, Kraków.

SP - SŁaWski Franciszek, red., 1974-2001, Słownik prasłowiański, t. 1-8, Wrocław.

Srezn. - Срезневский Измаил Иванович, 1989, Словарь древнерусского языка, т. 3, Москва [przedruk wyd. z 1912 r.].

SRJ - Словарь русского языка XI-XVII вв., 1975-2000, т. 1-24, Москва.

SStp. - UrbańcZYK Stanisław, red., 1953-2002, Słownik staropolski, Warszawa.

Stsł. - Цейтлин Раля Михайловна, Вечерка Радослав, Благова Эмилия, ред., 1994, Старославянский словарь (по рукописям Х-ХІ веков), Москва.

\section{Skróty konwencjonalne}

lm. - liczba mnoga

ros. - rosyjski

L sg - locativus singularis stpol. - staropolski (miejscownik liczby pojedynczej)

Zamieszczam tu skróty wszystkich wykorzystanych słowników oprócz słownika N. Tupikowa, zob. niżej w bibliografii Tupikov Nikołaj Michailovič, 1989. 
pol. - polski

por. - porównaj

przysł. - przysłówek

ps. $\quad-$ prasłowiański strus. - staroruski

wg - według

zob. - zobacz

\section{BIBLIOGRAFIA}

\section{Źródla}

КАЛАчов Николай Васильевич, ред., 1872-1877, Писцовыя книги Московского государства, часть 1, Писцовыя книги XVI века, отделение 1-2, Санкт-Петербург.

Писцовыя книги, издаваемыя Императорским Русским географическим обществом, часть 1, Указатель, Санкт-Петербург 1895 [jest to indeks do powyższej pozycji Kałaczow, 1872-1877].

\section{Opracowania}

BAŃKOwski Andrzej, 1984, Staropolskie imiona dwuczłonowe z osobliwymi składnikami, „Onomastica”, XXIX, s. 127-160.

BAZYLow Ludwik, 1975, Historia Rosji, Wrocław.

GARLICKI Andrzej, red., 1991, Poczet królów i książąt polskich, Warszawa.

Hertel Jacek, 1979, Problem dwuimienności u Piastów we wczesnym średniowieczu (do potomstwa Bolesława Krzywoustego włącznie), „Onomastica”, XXIV, s. 125-142.

HrynkiewicZ-AdAmskich Bożena, 2012, Siedemnastowieczne imiennictwo osobowe północnej Rosji na tle lokalnej kultury, Poznań.

KARPLUK Maria, 1957, Z badań nad polskim nazewnictwem osobowym XV i początków XVI wieku, „Onomastica”, III, s. 179-187, 381-392.

LECIEJEWICZ Lech, 1989, Słowianie zachodni. Z dziejów tworzenia się średniowiecznej Europy, Wrocław.

Malec Maria, 1971, Budowa morfologiczna staropolskich złożonych imion osobowych, Wrocław.

MaLec Maria, 1996, O imionach i nazwiskach w Polsce. Tradycja i współczesność, Kraków.

Malec Maria, 1998, Imiona, w: Polskie nazwy własne. Encyklopedia, red. E. Rzetelska-Feleszko, Warszawa - Kraków, s. 97-118.

MaLec Maria, 2001, Imię w polskiej antroponimii i kulturze, Kraków. 
MALEC Maria, 2002, Antroponimia I - Imiona, w: Słowiańska onomastyka. Encyklopedia, t. I, red. E. Rzetelska-Feleszko i in, Warszawa-Kraków, s. 298-303. MiLEwski Tadeusz, 1969, Indoeuropejskie imiona osobowe, Wrocław.

Skowronek Katarzyna, 1995, Imiona dwuczłonowe motywujące współczesne nazwiska polskie, „Onomastica”, XL, s. 73-100.

Skulina Tadeusz, 1974, Staroruskie imiennictwo osobowe, cz. II, Wrocław.

Sosnowski Jan, 2002, Toponimia rosyjska XVI wieku. Nazwy wsi, Łódź.

SosNowski Jan, 2012, Staroruskie dwuczłonowe imiona osobowe, w: Współczesne badania nad kulturą, literaturą i językiem rosyjskim, red. D. Paśko-Koneczniak, s. 437-450.

TuPIKov Nikolaj Michailowič, 1989, Wörterbuch der altrussischen Personennamen, mit einem Nachwort von Ernst Eichler, Köln, Wien [publikacja zawiera przedruk pracy Словарь древне-русскихъ личныхъ собственных именъ, Трудъ Н.М. Тупикова, С.-Петербургъ 1903].

Wóstowicz Marian, 1986, Древнерусская антропонимия XIV-XV вв. СевероВосточная Русь, Рoznań.

ВАСильЕВ Валерий Леонидович, 2005, Архаическая топонимия Новгородской земли (Древнеславянские деантропонимные образования). Великий Новгород, http://window.edu.ru/window_catalog/files/r46969/mion-novsu05.pdf (dostęp: 20.06.2009).

ЗАлизняк Андрей Анатольевич, 2004, Древненовгородский диалект, Москва. Зинин Сергей Иванович, 1972, Введение в русскую антропонимию, Ташкент. 